\title{
PENERAPAN PENDEKATAN INKUIRI TERBIMBING DENGAN METODE PICTORIAL RIDDLE UNTUK MENINGKATKAN PEMAHAMAN KONSEP FISIKA SISWA
}

\author{
Muhammad Minan Chusni \\ Pendidikan Fisika, Tarbiyah dan Keguruan, UIN Sunan Gunung Djati Bandung \\ Email: minan.chusni@uinsgd.ac.id
}

\begin{abstract}
Abstrak
Tujuan penelitian ini adalah mengetahui peningkatan pemahaman konsep fisika siswa melalui penerapan pendekatan inkuiri terbimbing dengan metide pictorial riddle pada pokok bahasan pesawat sederhana. Jenis penelitian yang dilakukan adalah penelitian tindakan kelas dengan subjek penelitian 29 siswa SMP Muhammadiyah Muntilan. Teknik yang digunakan dalam mengumpulkan data adalah dengan pengamatan langsung di kelas dan teknik tes. Adapun analisis datanya menggunakan analisis kualitatif dan kuantitatif.

Hasil penelitian menunjukkan bahwa penerapan pembelajaran inkuiri terbimbing dengan metode pictorial riddle mampu meningkatkan pemahaman konsep siswa pada siklus I dengan rata-rata nilai 42,93 menjadi 50,71 dan pada siklus II naik menjadi 67,50 serta pada siklus III menjadi 80,71. Begitu pula dengan motivasi belajar siswa terhadap pelajaran fisika juga tergolong baik dengan hasil sebesar 63,57\%.
\end{abstract}

Kata Kunci : pemahaman konsep fisika, pendekatan inkuiri terbimbing, dan pictorial riddle.

\begin{abstract}
The purpose of this study was to determine students' improved understanding of physics concepts through the application of guided inquiry approach with metide pictorial riddle on the subject of a simple plane. Type of research is classroom action research with research subjects 29 students of SMP Muhammadiyah Muntilan.

Techniques used in collecting data is by direct observation in the classroom and the testing techniques. The analysis of data using qualitative and quantitative analysis.

The results showed that the application of guided inquiry learning with pictorial riddle method can improve students' understanding of the concept in the first cycle with an average value of 42.93 into 50.71 and the second cycle increased to 67.50 and in the third cycle into 80.71. Similarly, the students' motivation to learn physics class is also quite good with a yield of $63.57 \%$.
\end{abstract}

Keywords: understanding the concepts of physics, guided inquiry approach, and pictorial riddle. 


\section{PENDAHULUAN}

Bidang pendidikan mengenalkan IPA mulai dari jenjang pendidikan dasar (SD) kemudian SMP, SMA, dan Perguruan Tinggi. Materi IPA di SMP secara tidak langsung merupakan kelanjutan dari materi IPA di SD. Namun materi IPA di SMP sudah terbagi menjadi Biologi, Fisika dan Kimia. Sehingga pada UAN SMP, Fisika tergabung menjadi IPA bersama Biologi dan Kimia yang baru masuk materi IPA SMP sejak beberapa tahun terakhir ini. Berhubung materi IPA di SMP sudah terbagi menjadi Biologi, Fisika, dan Kimia, maka proses pembelajarannya juga terpisah menjadi tiga dan diampu oleh masing-masing guru yang bersangkutan. Namun tidak menutup kemungkinan bahwa guru fisikapun harus bisa mengajar biologi atau kimia begitu juga sebaliknya.

Berdasarkan observasi, proses pembelajaran fisika di SMP Muhammadiyah Muntilan terbagi menjadi dua, yaitu proses pembelajaran di kelas dan proses pembelajaran di laboratorium. Proses pembelajaran di kelas lebih menekankan pada penjelasan materi secara ceramah dan latihan soal-soal. Sehingga banyak siswa yang merasa jenuh dan kurang menyukai pelajaran fisika. Siswa kurang memahami konsep- konsep fisika yang disampaikan guru dengan cara ceramah dan latihan soal-soal. Sedangkan proses pembelajaran di laboratorium, berupa kegiatan praktikum. Namun tidak semua materi bisa dipraktikan. Hal ini karena keterbatasan laboratorium yang biasanya dipakai secara bersamaan. Karena alasan inilah maka banyak materi fisika yang disampaikan guru dengan metode ceramah di kelas.

Mata pelajaran fisika memiliki karakteristik khusus, yakni kebenaran yang Begitu banyak anak didik yang mengeluh ketika belajar fisika. Hal inilah yang menyebabkan mereka kurang bersemangat dalam mengikuti pelajaran fisika. Motivasi belajar mereka terhadap fisika masih rendah jika dibandingkan dengan motivasi belajar mereka terhadap mata pelajaran lainnya. Karena banyaknya rumus yang harus 
Muhammad Minan Chusni- Penerapan Pendekatan Inkuiri ...

mereka hafal menyebabkan pelajaran fisika menjadi kurang menyenangkan dan kurang menarik. Bahkan banyak juga siswa yang sebenarnya tidak mengetahui asal mula ditemukannya rumus yang mereka hafalkan tersebut. Bedasarkan penjabaran pelaksanaan proses pembelajaran fisika, maka seorang guru harus bisa mensiasati agar proses pembelajaran tersebut bisa berjalan lebih baik meskipun pembelajaran tersebut berlangsung di dalam kelas. Salah satu pendekatan yang dapat diterapkan dalam situasi ini adalah pendekatan dengan cara penyelidikan. Pendekatan ini dikenal dengan nama pendekatan inkuiri. Pendekatan inkuiri merupakan suatu cara pembelajaran yang menghadapkan siswa kepada suatu masalah. Bila masalah dirumuskan oleh siswa dan mendesain serta merumuskan sendiri serta mengumpulkan dan menganalisis data sampai mengambil kesimpulan maka pendekatan ini termasuk pendekatan inkuiri. (Zuhdan Kun Prasetyo, 2001:2.4). Pada pendekatan inkuiri, apa yang diperoleh siswa sebagian besar didasarkan pada hasil usaha siswa sendiri atas dasar pengetahuan yang dimiliki siswa. Pembelajaran melalui pendekatan inkuiri tentunya akan membawa dampak besar bagi perkembangan mental yang positif pada siswa. Sebab melalui pendekatan inkuiri siswa mempunyai kesempatan yang luas untuk mencari dan menemukan sendiri apa yang dibutuhkannya kemudian memecahkan permasalahan tersebut melalui pengamatan, eksplorasi, dan prosedur penelitian. (Mulyasa, 2007:109). Bentuk pendekatan ini terutama memberikan motivasi kepada siswa untuk menyelidiki masalah-masalah yang ada dengan menggunakan cara-cara dan keterampilan ilmiah dalam rangka mencari penjelasanpejelasannya. Motivasi sangat diperlukan untuk mengerakkan, mengarahkan dan memperkuat tingkah laku siswa khususnya dalam proses pembelajaran siswa meliputi motivasi instrinsik dan ekstrinsik. (Elida Prayitno, 1989: 31)

Pada penelitian ini, pendekatan inkuiri yang akan dilakukan adalah dengan menggunakan metode 
pictorial riddle. Metode pictorial riddle adalah salah satu metode untuk mengembangkan motivasi dan minat siswa di dalam diskusi kelompok kecil dan besar. Metode pictorial riddle biasanya menggunakan media gambar atau sejenisnya. Gambar atau peragaan, atau situasi yang sesungguhnya dapat digunakan untuk meningkatkan cara berpikir kritis dan kreatif siswa. Suatu riddle biasanya berupa gambar di papan tulis, papan poster, pada lembar kegiatan siswa atau diproyeksikan dari suatu transparansi, kemudian guru mengajukan pertanyaan yang berkaitan dengan riddle itu. (Moh Amien, 1987: 150).

Proses pembelajaran melalui pendekatan inkuiri dengan metode pictorial riddle tidak harus berlangsung di laboratorium, tetapi juga dapat berlangsung di kelas. Karena itulah maka pada penelitian ini akan meneliti pengaruh penggunaan pendekatan inkuiri terbimbing dengan metode Pictorial Riddle terhadap peningkatan pemahaman konsep dan motivasi belajar fisika.
Pesawat Sederhana merupakan salah satu konsep esensial dalam fisika perlu mendapatkan perhatian, khususnya perhatian guru terhadap keterkaitan dengan konsep-konsep lain serta terapannya dalam kejadian nyata sehari-hari. Dalam kaitan ini telaah gelombang berfokus pada kajian tuas, katrol dan bidang miring.

Berdasarkan uraian yang dikemukakan di atas, kiranya perlu dilakukan penelitian yang dapat memberikan gambaran tentang implementasi model pembelajaran inkuiri terbimbing dengan metode pictorial riddle untuk meningkatkan motivasi dan pemahaman konsep fisika siswa kelas VIII SMP Muhammadiyah Muntilan.

\section{METODE}

Penelitian ini menggunakan setting tindakan kelas. Penelitian tindakan kelas adalah salah satu jenis penelitian tindakan yang dilakukan guru untuk meningkatkan kualitas pembelajaran di kelasnya (Pardjono dkk, 2007: 12). Model ini dipilih didasarkan pada tujuan penelitian yang ingin dicapai. 
Muhammad Minan Chusni- Penerapan Pendekatan Inkuiri ...

Penelitian dilakukan di SMP tersebut dapat lebih dioptimalkan, dan Muhammadiyah Muntilan. Kelas siswa belum pernah diberi yang akan diteliti adalah kelas VIII A pembelajaran dengan pendekatan dengan jumlah 29 siswa. inkuiri terbimbing dengan metode Pengambilan subjek penelitian ini pictorial riddle.

dipilih berdasarkan observasi awal Adapun proses penelitian tindakan yang telah dilakukan oleh peneliti, dapat digambarkan seperti pada bahwa aktivitas belajar siswa gambar 1.

terhadap pelajaran fisika di kelas

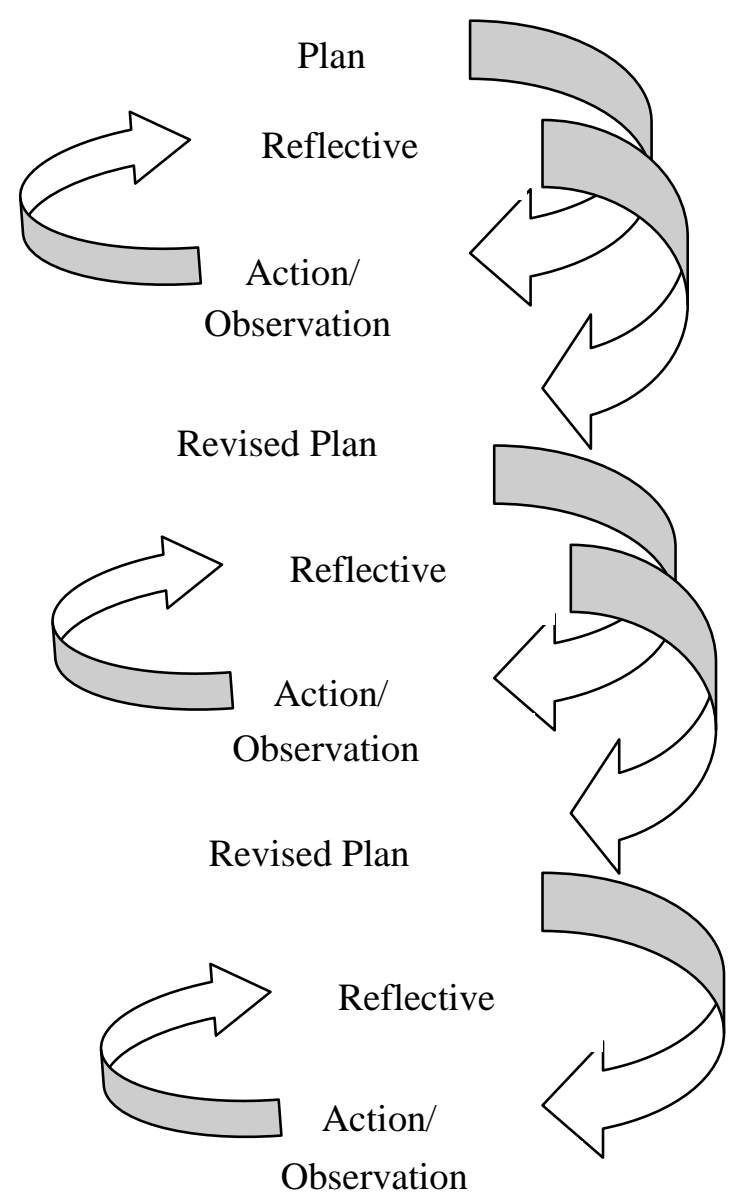

Gambar 1. Spiral PTK 
Teknik pengumpulan data untuk minat dan tanggapan terhadap metode pembelajaran yang dilakukan adalah dengan cara siswa mengisi angket, sedangkan pengumpulan data mengenai aktivitas siswa dinilai langsung pada saat proses pembelajaran dengan lembar observasi yang telah dipersiapkan sebelumnya, sedangkan untuk kemampuan kognitif siswa dilihat dari kemampuan mengerjakan soal postes yang diberikan setelah proses pembelajaran selesai.

Untuk mendapatkan data-data yang diperlukan dalam penelitian ini dilakukan langkah-langkah sebagai berikut: (a) melakukan observasi awal mengenai permasalahan yang berhubungan dengan pembelajaran fisika, (b) merancang dan menentukan bentuk LKS serta tindakan yang akan dilakukan, (c) membagikan angket minat siswa sebelum dan sesudah proses pembelajaran dilaksanakan, (d) melakukan observasi/pengamatan untuk memperoleh data yang berupa aktivitas siswa dan guru selama proses pembelajaran dengan lembar penilaian aktivitas yang sudah dipersiapkan sebelumnya, implementasi model pembelajaran inkuiri terbimbing dengan pictorial riddle, (f) menganalisis hasil pekerjaan siswa dalam LKS sebagai penilaian kelompok, (g) mendokumentasikan kegiatan siswa selama pembelajaran dalam bentuk gambar/foto, (h) merencanakan tindakan yang akan dilakukan selanjutnya.

Teknik analisis data yang digunakan dalam penelitian ini terdiri dari dua jenis analisis, yaitu : (1) Analisis kualitatif, diperlukan untuk menggambarkan suasana pembelajaran di kelas. Data diperoleh dari pengamatan. Analisis data dilakukan dengan cara peneliti merefleksi hasil observasi terhadap proses pembelajaran yang dilaksanakan di dalam kelas. Penyajian data dilakukan dalam rangka penyusunan informasi secara sistematis mulai dari perencanaan, pelaksanaan tindakan, pengamatan, dan refleksi pada masing-masing siklus. Dalam penyajian data ini dilakukan proses penampilan data secara lebih sederhana dalam bentuk paparan naratif. Data kualitatif divalidasi 
dengan triangulasi dan pengecekan kembali fakta sumber. (2) Analisis kuantitatif digunakan untuk memberikan gambaran tentang kemajuan atau peningkatan kualitas pembelajaran di kelas, dan untuk melihat perkembangan pemahaman konsep siswa. Data kuantitatif diperoleh dari hasil angket minat dan respon siswa, lembar observasi kelas yang berupa lembar aktivitas guru dan aktivitas siswa, dan lembar penilaian LKS. Data yang diperoleh dianalisis dan disajikan dalam bentuk persentase. (Ngalim Purwanto, 2002: 103).

\section{HASIL DAN PEMBAHASAN}

Berikut ini disajikan data hasil pengamatan sesuai dengan instrumen penelitian yang digunakan.

1. Hasil Pekerjaan Siswa dalam LKS

$\begin{array}{ccr}\text { Hasil } & \text { penilaian } & \text { LKS } \\ \text { kelompok } & \text { sebagai } & \text { penilaian } \\ \text { pemahaman } & \text { konsep } & \text { disajikan } \\ \text { pada tabel berikut. } & \end{array}$

Tabel 1. Hasil Penilaian LKS Kelompok

\begin{tabular}{cccc}
\hline \multirow{2}{*}{ Kelompok } & \multicolumn{3}{c}{ Penilaian LKS Kelompok (\%) } \\
\cline { 2 - 4 } & Siklus I & Siklus II & Siklus III \\
\hline A & 55.0 & 75,0 & 95.0 \\
B & 25.0 & 55.0 & 100.0 \\
C & 45.0 & 75.0 & 100.0 \\
D & 35.0 & 75.0 & 60.0 \\
E & 60.0 & 75.0 & 85.0 \\
F & 40.0 & 75.0 & 95.0 \\
G & 65.0 & 75.0 & 100.0 \\
H & 65.0 & 75.0 & 85.0 \\
I & 60.0 & 60.0 & 80.0 \\
\hline Rata-rata & 50,0 & 70,6 & 88,9 \\
\hline
\end{tabular}

Pada siklus I, percobaan dilakukan dengan berpedoman pada LKS I untuk topik materi tuas. Berdasarkan analisis hasil pekerjaan siswa pada LKS I dan sesuai pengamatan selama pembelajaran, kemampuan siswa dalam memahami, menganalisis, memecahkan, dan menyimpulkan masalah dari percobaan yang dilakukan belum baik, sehingga untuk 
dapat lebih mengoptimalkannya perlu adanya bimbingan dan pengarahan dari guru. Rata-rata hasil pekerjaan siswa dalam LKS I adalah 50\%.

Pada siklus II, digunakan LKS II sebagai pedoman siswa dalam melakukan percobaan dan menemukan konsep tentang katrol. Dalam LKS II ini, permasalahan dalam percobaan disesuaikan dengan kemampuan berpikir siswa dalam menganalisis, memecahkan, dan menyimpulkan masalah yang ditemukan, serta diharapkan siswa mampu menerapkannya dalam kehidupan sehari-hari. Dari hasil pengamatan, kemampuan siswa dalam menemukan konsep telah mengalami peningkatan jika dibandingkan dengan siklus I. Hal ini dapat dilihat dari peningkatan ratarata hasil pekerjaan siswa dalam LKS II, yaitu mencapai 70,2 \% dengan kenaikan nilai rata-rata LKS I ke nilai rata-rata LKS II sebesar $1,41 \%$ sehingga tergolong tinggi peningkatannya.

Pada siklus III, digunakan LKS III sebagai pedoman siswa dalam melakukan percobaan dan menemukan konsep tentang bidang miring. Dalam LKS III ini digunakan tipe yang sama dengan LKS sebelumnya dengan memperhatikan alokasi waktu dan kejelasan masalah. Dari hasil pengamatan, kemampuan siswa dalam menemukan konsep telah mengalami peningkatan jika dibandingkan dengan siklus II . Hal ini dapat dilihat dari peningkatan ratarata hasil pekerjaan siswa dalam LKS II, yaitu mencapai 88,9 \% dengan kenaikan nilai rata-rata LKS II ke nilai rata-rata LKS III sebesar 2,98\% sehingga tergolong tinggi peningkatannya.

2. Hasil Penilaian Kognitif

Hasil penilaian mencerminkan tingkat penguasaan konsep fisika siswa, dimana pada tahap ini siswa diberikan soal pretes dan postes untuk mengetahui sejauh mana siswa dapat menguasai konsep. Analisis hasil evaluasi kognitif pada setiap siklus dapat dilihat pada tabel 2 .

Rata-rata hasil posttest siswa dari siklus I ke siklus II mengalami peningkatan yang cukup baik, dengan kenaikan rata-rata posttest I ke posttest II sebesar 7,79. Pada hasil posttest siklus I masih ada 22 siswa yang skornya kurang dari indikator 
yang harus dicapai yaitu minimal 70 .

Pada hasil posttest siklus II masih ada

12 siswa yang skornya kurang dari indikator yang harus dicapai yaitu minimal 70. Pada hasil posttest siklus

III juga masih ada 5 siswa yang nilainya belum mencapai indikator minimal tetapi secara ketuntasan klasikal sudah $83 \%$ sehingga pemberian siklus dapat di hentikan.

Tabel 2. Hasil Pretes dan Postes

\begin{tabular}{lc}
\hline \multicolumn{1}{c}{ Jenis } & Rata-rata nilai \\
\hline Pretest & 42,93 \\
Posttes Siklus I & 50,71 \\
Posttes Siklus II & 67,50 \\
Posttes Siklus III & 80,71 \\
\hline
\end{tabular}

3. Hasil Penilaian Motivasi Siswa

Pengisian angket respon dilakukan diakhir pembelajaran, dimana pengisian diberikan kepada siswa hanya pada siklus III. Presentase ratarata hasil angket respon siswa terhadap pembelajaran yang telah dilaksanakan adalah $63,57 \%$. Sesuai dengan kriteria yang telah ditentukan maka respon siswa dapat digolongkan pada kriteria baik.

Berdasarkan uraian diskripsi data hasil penelitian di atas maka, dapat dilihat adanya dua keberhasilan pembelajaran, yaitu keberhasilan proses dan keberhasilan produk, dengan uraian sebagai berikut:
1. Keberhasilan Proses

Keberhasilan proses pada penelitian ini dapat dilihat dari aktivitas siswa pada saat proses pembelajaran dan angket respon siswa terhadap pembelajaran. Hasil dari penelitian mulai dari siklus I, siklus II dan siklus III ini akan dibahas secara rinci seperti di bawah ini.

a. Hasil Aktivitas Siswa

Aktivitas siswa pada siklus I termasuk kategori kurang baik. Pada saat proses menjelaskan prosedur kegiatan beberapa siswa tidak focus memperhatikan arahan guru hal ini berakibat pada kesulitan pada saat 
pemecahan masalah yang ada pada LKS kegiatan 1 yang berkaitan dengan hasil pekerjaan siswa.

Setelah dilakukan refleksi untuk memecahkan permasalahan yang muncul maka pelaksanaan siklus II semua kelompok dapat melakukan aktivitas dengan baik, sehingga dalam menyelesaikan permasalahan yang berkaitan dengan LKS kegiatan 2 dapat diselesaikan dengan baik. Suasana kelas lebih kondusif dan siswa dapat mengerjakan LKS dengan benar tetapi interaksi diskusi antar kelompok belum berjalan dengan semestinya karena masih di dominasi oleh siswa yang berkemampuan tinggi sedangkan siswa yang berkemampuan rendah hanya diam dan kurang aktif membantu menyelesaikan.

Setelah dilakukan refleksi untuk memecahkan permasalahan yang muncul maka pelaksanaan siklus III yaitu dengan bimbingan dan motivasi yang dilakukan guru kepada siswa baik individu maupun menyeluruh sehingga keterlibatan siswa dalam berdiskusi atau kerjasama dapat optimal. Hal ini terlihat pada siswa lebih bersemangat, kerjasama kelompok juga sudah terjalin, dan telihat siswa lebih berani menyampaikan pendapat kepada sesama anggota kelompok.

\section{Keberhasilan Produk}

Pembelajaran fisika dianggap berhasil apabila mampu menghubungkan produk yang rasional dengan produk empiris. Keberhasilan produk ini dapat dilihat dari penilaian pretes, postes, dan lembar kerja siswa sebagai hasil penilaian. Hasil penilaian mulai dari siklus I, siklus II dan siklus III ini akan dibahas secara rinci seperti berikut.

\section{a. Pretes dan Postes}

Hasil penilaian mencerminkan tingkat penguasaan konsep fisika siswa, dimana pada tahap ini siswa diberikan soal pretes dan postes untuk mengetahui sejauh mana siswa dapat menguasai konsep. Hasil penilaian kognitif siswa dalam bentuk pretest dan posttest merupakan salah satu indikator keberhasilan produk pembelajaran. Rata-rata hasil posttest siswa dari siklus I ke siklus II dan ke siklus III mengalami peningkatan yang baik, sebagimana disajikan pada gambar 2. 
Muhammad Minan Chusni- Penerapan Pendekatan Inkuiri ...

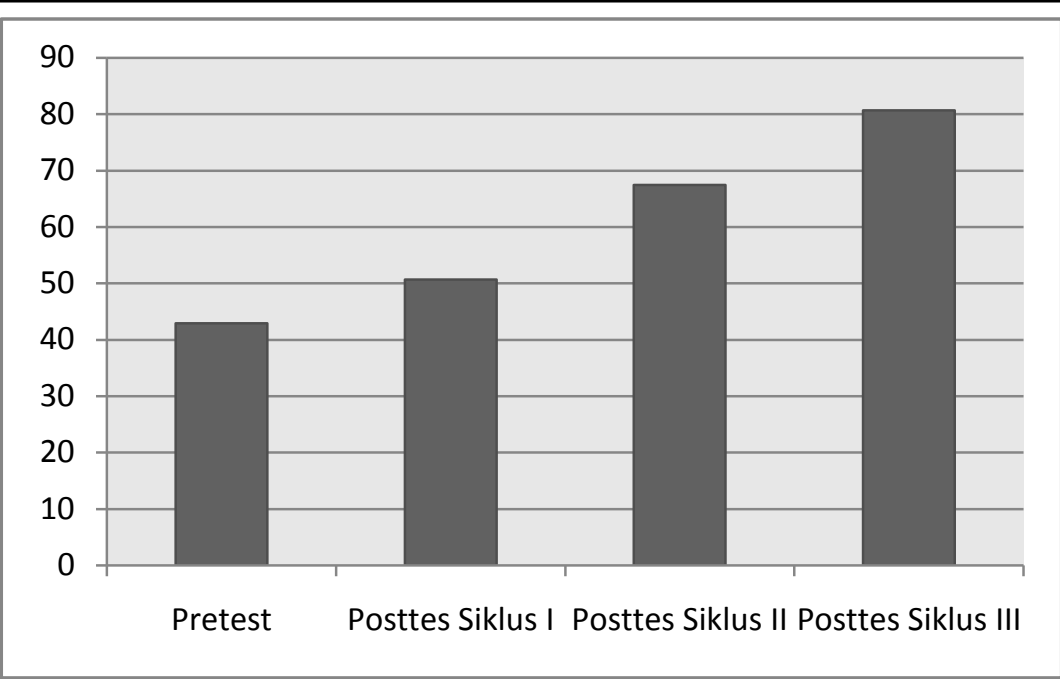

Gambar 2. Grafik Nilai Rata-Rata Pretes dan Postes

b. Hasil Penilaian LKS

Keberhasilan produk ini dapat juga dilihat dari lembar kerja siswa sebagai hasil evaluasi kognitif. Lembar Kerja Siswa digunakan siswa sebagai pedoman untuk bahan diskusi kelompok untuk merumuskan konsep fisika. Berdasarkan hasil penelitian diperoleh hasil penilaian lembar kerja siswa dalam kelompok pada siklus I adalah sebesar 50,0; kemudian mengalami kenaikan sehingga pada siklus II menjadi 70,6; kemudian mengalami kenaikan sehingga pada siklus III menjadi 88,9. Hasil penilaian lembar kerja siswa dalam kelompok pada setiap siklus termasuk dalam kategori sangat tinggi. Ini menunjukkan bahwa siswa sudah paham dengan konsep-konsep fisika yang dipelajari.

Dari hasil rata-rata penilain LKS pada siklus I, II dan III dapat disajikan pada gambar 3.

Berdasarkan uraian tersebut, dapat diketahui bahwa keberhasilan dari penelitian ini terlihat dari peningkatan proses yang diikuti dengan peningkatan produk pembelajaran. Lembar kerja siswa yang digunakan sebagai pedoman belajar juga mengalami peningkatan. Hal ini berarti bahwa siswa paham dengan konsep-konsep fisika yang diselidiki dengan menggunakan metode pembelajaran ini. Dengan demikian lembar kerja siswa juga dapat meningkatkan aktivitas siswa pada saat diskusi. Setelah dilakukannya 
pembelajaran melalui penerapan peningkatan setelah dilakukannya pendekatan inkuiri terbimbing dengan metode pembelajaran tersebut. pictorial riddle mengalami

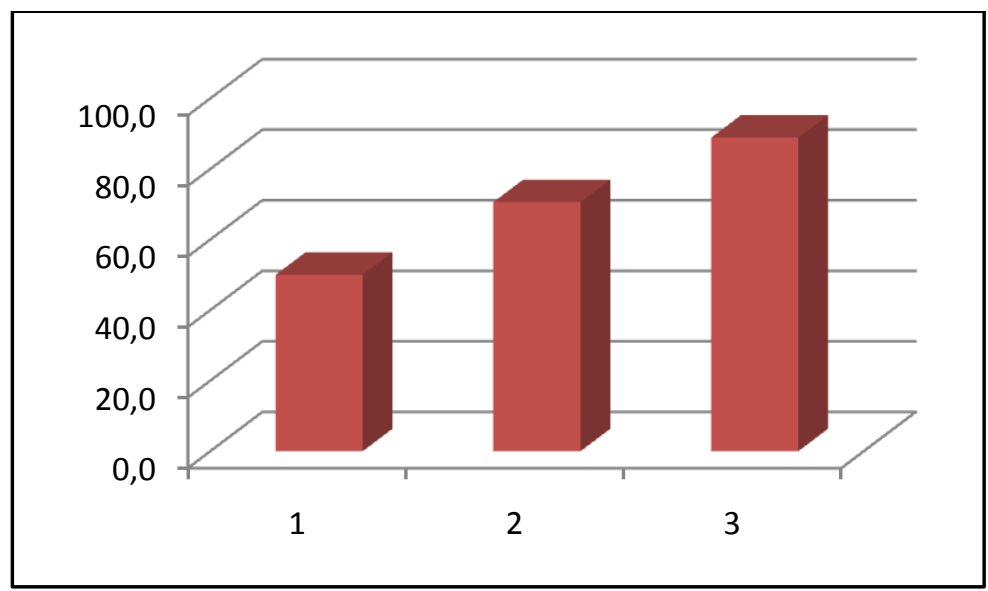

Gambar 3. Persentase nilai rata-rata LKS kelompok pada siklus I, II dan III.

Faktor yang mempengaruhi prestasi belajar yaitu faktor internal dan faktor eksternal. Faktor internal dapat dilihat dari aktivitas siswa, sedangkan faktor eksternal dilihat dari metode pembelajaran yang digunakan. Dengan peningkatan penguasaan konsep maka akan berdampak pada pemahaman konsep siswa dan hasil belajarnya. Dilihat dari nilai awal dan nilai akhir siswa terjadi peningkatan yang ditunjukkan dari nilai rata-rata kelas sebelum dilaksanakan tindakan yaitu 50,00 menjadi 80,71 setelah dilaksanakan tindakan.
Setelah menganalisis hasil tindakan pada setiap siklusnya, dapat diketahui bahwa hasil data tiap siklus mengalami peningkatan meskipun tidak seberapa. Dengan tercapainya peningkatan pemahaman konsep fisika siswa seperti yang sudah dijelaskan di atas, maka pelaksanaan tindakan yang telah dilakukan dalam siklus I, siklus II dan siklus III dapat meningkatkan pemahaman konsep fisika siswa khususnya pesawat sederhana. Penelitian ini ada kemungkinan diteruskan untuk siklussiklus berikutnya. Akan tetapi, karena keterbatasan waktu dan materi pembelajaran, peneliti menganggap 
penelitian ini dirasa cukup untuk dilaksanakan sampai dengan siklus III. Dengan ketercapaian ini, tindakan penelitian dipandang sudah dapat diberhentikan.

\section{PENUTUP}

\section{Kesimpulan}

Berdasarkan hasil pembahasan, maka dapat disimpulkan bahwa penerapan pembelajaran inkuiri terbimbing dengan metode pictorial riddle mampu meningkatkan pemahaman konsep siswa pada siklus I dengan rata-rata nilai 42,93 menjadi 50,71 dan pada siklus II naik menjadi 67,50 serta pada siklus III menjadi 80,71 . Begitu pula dengan motivasi belajar siswa terhadap pelajaran fisika juga tergolong baik dengan hasil sebesar $63,57 \%$.

\section{Saran}

Perlu melakukan penelitian tindakan sejenis dengan subjek penelitian yang lebih banyak dan rentang waktu yang lebih panjang dengan karakteristik siswa yang berbeda/tertentu untuk memperoleh hasil yang lebih baik.

\section{DAFTAR PUSTAKA}

Elida Prayitno. (1989). Motivasi Dalam Belajar. Jakarta: Depdiknas Dirjen Pendidikan Tinggi Proyek Pengembangan Lembaga Pendidikan Tenaga Kependidikan

Moh Amien. (1987). Mengajarkan Ilmu Pengetahuan Alam (IPA) Dengan Menggunakan Metode "Discovery" dan "Inquiry". Jakarta: Departemen Pendidikan dan Kebudayaan Direktorat Jenderal Pendidikan Tinggi Proyek Pengembangan Lembaga Pendidikan Tenaga Kependidikan.

Mulyasa. (2007). Menjadi Guru Profesional. Bandung: PT Remaja Rosdakarya

Ngalim Purwanto.2002. Prinsipprinsip dan Teknik Evaluasi Pengajaran. Bandung: PT Remaja Rosdakarya.

Pardjono,dkk. 2007. Panduan Penelitian Tindakan Kelas. Lembaga Penelitian Universitas Negeri Yogyakarta.

Zuhdan Kun Prasetyo. (2001). Kapita Selekta Pembelajaran Fisika. Jakarta: Pusat Penerbitan Universitas Terbuka 